\title{
Phytochemical Analysis of Phyllanthus Maderaspatensis And Celosia Argentea
}

\author{
S. Swarupa Rani ${ }^{1}$, R.R.Venkata Raju ${ }^{2}$ \\ ${ }^{1}$ The Adoni Arts \& Science College, Adoni,India. \\ ${ }^{2}$ Department of Botany,Sri Krishnadevaraya University,Ananthapur,India
}

\begin{abstract}
Phyllanthus maderaspatensis a dominant weed in Jowar fields and Celosia argentea a dominant weed in Redgram fields were identified by the IVI studies conducted in the test fields of Kurnool district, Andhra Pradesh. Though they are weed plants they have medicinal value .Being the test weeds are known ethanobotanicals in the area root and shoot extracts were analysed to indicate the quality/groups of secondary metabolites.
\end{abstract}

Keywords : Phyllanthus maderaspantensis, Celosia argentea, Phytochemical analysis,

\section{Introduction :}

Phyllanthus maderaspantensis and Celosia argentea both are dominant weed plants in crops of Jowar and Redgram respectively. Interestingly both are ethanomedicinals in the test area their phytochemical analysis was carried out.

P. maderaspatensis herb is bitter in taste, possess several medicinal properties like astringent, debostruent, stomachic diuretic, febrifugeal and antiseptic properties. The leaves are expectorant, diaphoretic useful in strangury and sweats. The seeds have a bad taste used as carminative laxative, astringent to the bowels tonic to the liver diuretic useful in bronchitis .

Celosia argentea consumed as vegetable leaves and shoots are edible used in curry. The seeds are used medicinally as an opthalmic, antiphologistic and astringent in conjuctivitis or retinal haemorrhage. . The purpose of this work was to perform the chemical prospection of the different extracts and to evaluate the phytochemical compounds of Phyllanthus maderaspatensis and Celosia argentea extracts.

\section{Materials and Methods :}

Preliminary phytochemical analysis was undertaken using standard qualitative method described by Amarsingham et al 1964.

Plant material : Fresh parts of each plant species viz root, stem, leaf and inflorescence or whole plants were collected during the exploration tips and thoroughly washed with running tap water followed by sterile distilled water. Excised plant parts were shade dried at room temperature pulverised and passed through 64 mesh sieve in order to get coarse powder.

Preparation of crude extracts : For qualitative detection about $100 \mathrm{~g}$ of the powdered test material was loaded in soxhlet and fractionated sequentially in $200 \mathrm{ml}$ of petroleum ether, ethanol and water successively over 6-8 hrs or the extraction was continued until the liquid was clear. The extracts obtained were filtered and concentrated under reduced pressure below $40^{\circ} \mathrm{C}$ to dryness and the residue used for the tests.

The rational for adopting such a sequential extraction procedure was based on the polarity of solvents that could leach out compounds soluble in that particular solvent (Waltor, 1971).

\section{Results :}

\section{Phytochemical analysis of solvent extracts of two weeds}

\begin{tabular}{|c|c|c|c|c|c|c|c|c|c|c|c|c|c|}
\hline \multirow{3}{*}{$\begin{array}{l}\text { S. } \\
\text { No. }\end{array}$} & \multirow{3}{*}{$\begin{array}{l}\text { Name of the } \\
\text { Secondary metabolites }\end{array}$} & \multicolumn{6}{|c|}{ Phyllanthus maderaspatensis } & \multicolumn{6}{|c|}{ Celosia orgentia } \\
\hline & & \multicolumn{3}{|c|}{ Root Extract } & \multicolumn{3}{|c|}{ Shoot Extract } & \multicolumn{3}{|c|}{ Root Extract } & \multicolumn{3}{|c|}{ Shoot } \\
\hline & & $\mathrm{Pe}$ & $\mathrm{M}$ & $\mathrm{W}$ & $\mathrm{Pe}$ & $\mathrm{M}$ & $\mathrm{W}$ & $\mathrm{Pe}$ & $\mathrm{M}$ & $\bar{W}$ & $\mathrm{Pe}$ & $\mathrm{M}$ & $\mathrm{W}$ \\
\hline \multirow{2}{*}{1} & \multirow[t]{2}{*}{ Alkaloids } & - & + & + & + & + & + & + & + & + & + & + & + \\
\hline & & - & + & - & - & - & - & - & + & + & + & + & - \\
\hline 2 & Anthocyanins & - & - & - & $\operatorname{tr}$ & + & $\operatorname{tr}$ & - & - & - & - & - & - \\
\hline 3 & Anthocyanidins & - & - & - & + & ++ & + & - & - & - & - & - & - \\
\hline
\end{tabular}




\begin{tabular}{|c|c|c|c|c|c|c|c|c|c|c|c|c|c|}
\hline 4 & Anthracene glycosides & - & - & - & - & ++ & + & - & - & - & - & + & - \\
\hline 5 & Antraquinones & - & - & - & - & - & - & - & - & - & - & + & - \\
\hline 6 & Coumarins & - & + & - & - & - & + & - & - & + & & & \\
\hline 7 & Flavonoids & - & + & + & - & + & - & - & - & - & + & - & - \\
\hline 8 & Flavones & - & - & + & - & + & - & - & - & - & + & - & - \\
\hline 9 & Flavonols & - & $\begin{array}{l}+ \\
+\end{array}$ & + & - & + & - & - & + & - & + & - & - \\
\hline 10 & Phenols & - & + & - & - & + & - & - & - & - & + & + & + \\
\hline 11 & Dihydrochalcones & - & + & - & - & + & - & - & - & - & + & - & - \\
\hline 12 & Catacholic compound & - & + & - & $\operatorname{tr}$ & + & + & - & - & - & - & + & - \\
\hline 13 & Iridoids & + & + & + & + & + & + & + & + & + & + & + & + \\
\hline
\end{tabular}

Phytochemical constitution: richness of secondary metabolites in different parts of test plants.

\begin{tabular}{|l|l|l|}
\hline S.No. & Name of the extract & $\%$ of richness \\
\hline 1 & Phyllanthus (roots) & 57.1 \\
\hline 2 & Phyllanthus (shoots) & 66.6 \\
\hline 3 & Celosia (roots) & 28.5 \\
\hline 4 & Celosia (shoots) & 71.4 \\
\hline
\end{tabular}

\section{Discussion}

Results (Table 1) revealed that among all the metabolites, alkaloids, iridoids and flavonoids are common in test species than other compounds. Percentage of richness of chemical compounds is more in shoots than in roots sample (Table 2).

\section{Conclusion}

Secondary metabolites have a broad range of applications in the pharmaceutical, chemical and food industry. Results revealed that among all the metabolites alkaloids, Iridoids and flavanoids are common in test species than other compounds. Percentage of richness of chemical compounds are more in shoots than in root system. Phyllanthus shoot with 66.6 and Celosia shoot with 71.4 percent richness of compounds.

\section{Acknowledgements :}

1. I am very thankful to the UGC for providing financial assistance to do this research work.

2. I am thankful to the research guide professor R. R. Venkata Raju for his guidance .

My thanks to the members of the management of The Adoni Arts and Science College, Adoni for supporting and encouragement

\section{References}

[1]. Amarasingham, R.P., Biset, N.G., Millard P.H , and Woods , M. C. 1964. Phytochemicl Survey of Malaya part II. Alkaloids and Saponins. J.Econ. Bot. 18: 270-278..

[2]. Camporese, A. 1997. L' aromatogramma: metodi, corretto, utillizzo, prospective di ricerea. Rivista Haliana Eppos 21, 4.

[3]. Koneman, E.W. 1995. Testo Atlante di Microbiologia Diagnostica, 2md ed. A.

[4]. Waltor H. F. 1971. Principle and methods of chemical analysis. Prentice- HALL Of India Pvt. Ltd., New Delhi.

[5]. Yu. J.Q., Lei, J.C., Yu, H, Cai, X. \& 204, G.1. 2004. Chemical composition and antimicrobial activity of the essential oil of Scutellaria barbata, phytochem 65:881-884. 